\title{
A STUDY ON CLINICAL EVALUATION OF DIABETIC RETINOPATHY AND ITS CORRELATION WITH SERUM HbAlC LEVEL
}

KEY WORDS: diabetic retinopathy, retinal degeneration, serum $\mathrm{HbAlc}$, ETDRS classification, NPDR, PDR

\section{Dr Debasmita} Mishra

Dr Deshish Kumar Panda*

Dr Prasant Kumar Nanda Dr Saiprasanna Behera
PG Department of Ophthalmology, Hi-Tech Medical College and Hospital, Pandra, Rasulgarh, Bhubaneswar, Odisha-751025.

Asst. Prof in Paediatrics, Santha Bhima Bhoi Medical College \& Hospital, Balangir. Odisha - 767001.*Corresponding Author

Professor of Department of Ophthalmology, Hi-Tech Medical College and Hospital, Pandra, Rasulgarh, Bhubaneswar, Odisha-751025.

Research Associate, CRO Pharmatrendz Private Limited. Bhubaneswar. Odisha-751014.

This cross-sectional clinical study titled "A clinical evaluation of diabetic retinopathy and its correlation with serum HbAlc level" was conducted in Hi-Tech medical college, Bhubaneswar from September 2019 to May 2021 by taking 67 patients from ophthalmological OPD who were diagnosed as cases of diabetic retinopathy, but not taking laser therapy and not having other non-diabetic causes of retinal degeneration and having diabetic mellitus of at least one year without considering type of diabetes or treatment taken by the patients. These 67 patients diagnosed as cases of diabetic retinopathy are classified according to their severity basing upon their findings( microaneurysm, exudates, retinal hemorrhages, venous beading, IRMA, new vessels in disc or elsewhere in retina) as per ETDRS(Abbreviated early treatment diabetic retinopathy study) classification as mild NPDR, moderate NPDR, severe NPDR, very severe NPDR, PDR. Their serum glycosylated haemoglobin ( $\mathrm{HbAl}$ ) level of each individual in each group is detected and then mean $\mathrm{HbAlc}$ level of each group derived and when correlated, we found that the mean $\mathrm{HbAl}$ lc for mild grade of retinopathy was found to be 7.667, for moderate non-proliferative diabetic retinopathy(NPDR) 8.450, for severe NPDR 9.700, for very severe NPDR 11.447 and for Proliferative Diabetic Retinopathy(PDR) the mean HbAlc value was found to be 11.468.The $\mathrm{P}$ value obtained through ANOVA test for HbAlc vs. grade of diabetic retinopathy was statistically significant (Sig : 0.000). The Eta \& Eta squared value for $\mathrm{HbAlc}$ vs grade of retinopathy was 0.695 and 0.483 . So the present study reveals that more severe grades of diabetic retinopathy manifesting in patients with higher levels of $\mathrm{HbAl}$.

\section{INTRODUCTION :-}

Diabetic retinopathy is predominantly a microangiopathy in which small blood vessels are affected and it is so prevalent that almost all of type land two third of all type 2 Diabetics are expected to develop diabetic retinopathy over a period of time ${ }^{1-3}$. Severity of diabetic retinopathy increases over period of time and the severity is diagnosed and classified basing upon their findings (microaneurysm, exudates, retinal hemorrhages, venous beading, IRMA, new vessels in disc or elsewhere in retina ) as per ETDRS classification ${ }^{4,5}$. Serum glycosylated hemoglobin ( $\mathrm{HbAlc}$ ) estimates the average glycemic status over weeks to months as per the lifespan of RBCs and is a prognostic marker as well as known to be a marker to access the long term control of diabetes mellitus ${ }^{6-8}$. Studies in the past have also shown that Hbalc level could be correlated with the long term complications of Diabetes mellitus in general ${ }^{9}$. Here the correlative study has done more specifically between Diabetic retinopathy with that of serum $\mathrm{HbAlc}$ level to establish clearly the association between these two ${ }^{10}$.

\section{MATERIALS AND IMETHODS :-}

A cross-sectional study was conducted in the Department of Ophthalmology, Hi-tech Medical College \& Hospital by taking 67 patients diagnosed as a case of diabetic retinopathy but not taking laser therapy and not having other non-diabetic causes of retinal degeneration and having diabetic mellitus of at least one year without considering type of diabetes or treatment taken by the patients. These 67 patients diagnosed as cases of diabetic retinopathy are classified according to their severity basing upon their findings( microaneurysm, exudates, retinal hemorrhages, venous beading , IRMA, new vessels in disc or elsewhere in retina) as per ETDRS (Abbreviated early treatment diabetic retinopathy study) classification as mild NPDR, moderate NPDR, severe NPDR, very severe NPDR, PDR. Their serum HbAlc level of each individual in each group is estimated and then mean $\mathrm{HbAlc}$ level of each group derived and then correlated between level of serum $\mathrm{HbAlc}$ and severity of diabetic retinopathy. Study was conducted only after being duly approved and permitted by the ethical committee and cases will be considered after written consent being taken from the patients.

\section{Statistical analysis:}

All values are presented as mean \pm standard deviation (SD) with $95 \%$ confidence intervals. Statistical differences between the parameters were tested using Chi-square test. The Statistical analysis of the study data was carried out using the SPSS statistical software (V. 16.0) (SPSS, Chicago, IL, USA).

The Fisher's exact test value obtained was 3.475 while the $P$ value was .970 which was not statistically significant $(P>0.05)$. The Pearson chi-square showed a $P$ value to be 0.962 which was also not significant. The degree of freedom was 8 for Pearson chi-square while for linear-by-linear association, the degree of freedom was one.

\section{RESULT \& DISCUSSION :-}

In the study, the 67 number of patients diagnosed as cases of diabetic retinopathy are classified into different grades as per "abbreviated early treatment diabetic retinopathy study" as:-

Table 1: Frequency of different grades of diabetic retinopathy

\begin{tabular}{|c|c|}
\hline Grades of diabetic retinopathy & Frequency \\
\hline Mild NPDR & 12 \\
\hline i. Microaneurysm & 4 \\
\hline ii. Microaneurysm and retinal hemorrhages & 5 \\
\hline $\begin{array}{l}\text { iii. Microaneurysm and retinal hemorrhages } \\
\text { and exudates(cotton wool spots) }\end{array}$ & 3 \\
\hline Moderate NPDR & 10 \\
\hline $\begin{array}{l}\text { I. Severe retinal haemorrhages (20 medium } \\
\text { - large per quadrants ) in } 1-3 \text { quadrants }\end{array}$ & 5 \\
\hline
\end{tabular}




\begin{tabular}{|l|c|}
\hline $\begin{array}{l}\text { ii. } \quad \text { significant venous beading in l quadrant } \\
\text { iii. } \begin{array}{l}\text { mild IRMA (intraretinal microvascular } \\
\text { anomaly) }\end{array}\end{array}$ & $\mathbf{5}$ \\
\hline Severe NPDR & $\mathbf{1 3}$ \\
\hline $\begin{array}{l}\text { i. } \quad \text { Severe retinal haemorrhages in all 4 } \\
\text { quadrants }\end{array}$ & $\mathbf{6}$ \\
\hline $\begin{array}{l}\text { ii. } \quad \text { Significant venous beading in } 2 \text { or more } \\
\text { quadrants }\end{array}$ & $\mathbf{4}$ \\
\hline iii. Moderate IRMA in l or more quadrants & $\mathbf{3}$ \\
\hline Very Severe NPDR & $\mathbf{1 3}$ \\
\hline i. $\quad$ i\&ii of Severe NPDR & $\mathbf{5}$ \\
\hline ii. i\&iii of Severe NPDR & $\mathbf{5}$ \\
\hline iii. i,ii\&iii of Severe NPDR & $\mathbf{3}$ \\
\hline PDR & $\mathbf{1 0}$ \\
\hline i. $\quad$ new vessels in the disc & $\mathbf{9}$ \\
\hline ii. $\quad$ new vessels elsewhere & \\
\hline
\end{tabular}

Table 2 : Prevalence ofDifferent Grades ofDiabetic Retinopathy

\begin{tabular}{|l|c|c|}
\hline \multicolumn{1}{|c|}{ GRADE } & FREQUENCY & PERCENTAGE(\%) \\
\hline Mild NPDR & 12 & $17.91 \%$ \\
\hline Moderate NPDR & 10 & $14.92 \%$ \\
\hline Severe NPDR & 13 & $19.4 \%$ \\
\hline Very severe NPDR & 13 & $19.4 \%$ \\
\hline PDR & 19 & $28.35 \%$ \\
\hline Total & $\mathrm{n}=67$ & $\mathrm{n} \%=100 \%$ \\
\hline
\end{tabular}

According to the study as per Table No. 2, majority of the patients had NPDR amounting to $71.64 \%(48)$ as compared to PDR in $28.35 \%(19)$. Severe (13) and very severe(13) NPDR had an equal prevalence of $19.4 \%$.

Again the serum $\mathrm{HbAlc}$ level of each individual in each grade is detected, then from these values the mean $\mathrm{HbAlc}$ level of the patients of each grade and the grand mean of all the grades is derived. Now from observed $\mathrm{HbAlc}$ value of each patient of each grade, mean $\mathrm{HbAlc}$ level of each grade and grand mean of all grades, the mean sum of squares between group and the mean sum of square within group derived and when put in ANOVA table by considering degree of freedom, we found the mean square, Eta squared, Eta, F statistic and finally the $P$ value such as :-

Table 3: Relationship between severity of diabetic retinopathy and serum $\mathrm{HbAl}$ c level

\begin{tabular}{|c|c|c|c|}
\hline \multicolumn{5}{|c|}{ HbAlc } \\
\hline Severity & Mean & N & Std. Deviation \\
\hline Mild & 7.667 & 12 & 1.9439 \\
\hline Moderate & 8.450 & 10 & 2.0162 \\
\hline Severe & 9.700 & 13 & 1.6010 \\
\hline Very severe & 11.477 & 13 & 1.1512 \\
\hline PDR & 11.468 & 19 & 1.6056 \\
\hline Total & 9.996 & 67 & 2.2397 \\
\hline
\end{tabular}

The mean $\mathrm{HbAlc}$ for mild grade of retinopathy was found to be 7.667, for moderate NPDR 8.450, for severe NPDR 9.700, for very severe NPDR 11.447 and for PDR the mean $\mathrm{HbAl}$ c value was found to be 11.468

Table 4: Relationship between severity of diabetic retinopathy and serum $\mathrm{HbAl}$ c level

\begin{tabular}{|l|l|c|c|c|c|c|}
\hline \multicolumn{7}{|c|}{ ANOVA TABLE } \\
\hline \multicolumn{2}{|c|}{} & $\begin{array}{c}\text { Sum of } \\
\text { Squares }\end{array}$ & Df & $\begin{array}{c}\text { Mean } \\
\text { Square }\end{array}$ & F & Sig. \\
\hline $\begin{array}{l}\text { HbAlc* } \\
\text { Severity }\end{array}$ & $\begin{array}{l}\text { Between } \\
\text { groups(combined) }\end{array}$ & 159.853 & 4 & 39.963 & 14.4 & .000 \\
& Within Groups & 171.216 & 62 & 2.762 & & \\
\cline { 2 - 8 } & Total & 331.069 & 66 & & & \\
\hline
\end{tabular}

Table 5 : Eta and Eta squared relationship between $\mathrm{HbAl}$ c vs. grades of retinopathy

\begin{tabular}{|c|c|c|}
\hline \multicolumn{3}{|c|}{ Measures of Association } \\
\hline & Eta & Eta Squared \\
\hline $\mathrm{HbAlc} *$ Severity & 0.695 & 0.483 \\
\hline
\end{tabular}

The $\mathrm{P}$ value obtained through ANOVA test was statistically significant(sig: 0.000) for $\mathrm{HbAlc}$ vs. grade of retinopathy. The Eta and Eta squared value for $\mathrm{HbAl} \mathrm{c}$ vs. grades of retinopathy was 0.695 and 0.483 respectively.

However in this study, the 67 numbers of diabetic retinopathy cases taken irrespective of the type of treatment taken by the patients such as oral hypoglycaemic agents or insulin. when we try to establish the relation between the different grades of diabetic retinopathy to that of oral hypoglycemic agent and insulin therapy, we found that :-

Table 6: Relationship Between Different Grades of Diabetic Retinopathy and Anti-Diabetic Medication

\begin{tabular}{|c|c|c|c|c|c|c|}
\hline Medication & Mild & Moderate & Severe & \begin{tabular}{|c|} 
Very \\
Severe
\end{tabular} & PDR & Tota] \\
\hline Insulin & $0(0 \%)$ & $\begin{array}{l}1(16.66 \% \\
l^{2}\end{array}$ & \begin{tabular}{|l|}
$2(33.3$ \\
$3 \%)$
\end{tabular} & \begin{tabular}{|l|}
$1(16.6$ \\
$6 \%)$
\end{tabular} & \begin{tabular}{|l|}
$2(33$. \\
$33 \%)$
\end{tabular} & $\begin{array}{l}6(10 \\
0 \%)\end{array}$ \\
\hline $\begin{array}{l}\text { Antidiabetic } \\
\text { OHA }\end{array}$ & $\begin{array}{l}11(19 . \\
64 \%)\end{array}$ & $\begin{array}{l}9(16.07 \% \\
)\end{array}$ & \begin{tabular}{|l|}
$10(17$. \\
$85 \%)$
\end{tabular} & \begin{tabular}{|l}
$11(19$. \\
$64 \%)$ \\
\end{tabular} & \begin{tabular}{|l|}
$15(26$ \\
$.78 \%)$ \\
\end{tabular} & \begin{tabular}{|l|}
$56(1$ \\
$00 \%)$
\end{tabular} \\
\hline Both & $\begin{array}{l}1(20 \\
\%) \\
\end{array}$ & $0(0 \%)$ & $\begin{array}{l}1(20 \% \\
\end{array}$ & $\begin{array}{l}1(20 \% \\
)^{2}\end{array}$ & \begin{tabular}{|l|}
$2(40$ \\
$\%)$
\end{tabular} & $\begin{array}{l}5(10 \\
0 \%) \\
\end{array}$ \\
\hline Total $=67$ & $\begin{array}{l}12(17 . \\
9 \%)\end{array}$ & $10(14.9 \%$ & $\begin{array}{l}13(19 . \\
4 \%)\end{array}$ & $\begin{array}{l}13(19 . \\
4 \%)\end{array}$ & $\begin{array}{l}19(28 \\
.4 \%)\end{array}$ & $\begin{array}{l}67(1 \\
00 \%)\end{array}$ \\
\hline
\end{tabular}

Out of a total of 67 patients, 56 were under oral hypoglycaemic agents as compared to only 6 who were taking insulin at the time of study. In the PDR group, 15(26.78\%) were taking OHA while $2(33.33 \%)$ were taking insulin to control their blood glucose level.

Table 7: Relationship between different grades of diabetic retinopathy and anti-diabetic medication

\begin{tabular}{|c|c|c|c|c|c|c|}
\hline \multicolumn{7}{|c|}{ Chi-Squre Tests } \\
\hline & Value & df & \begin{tabular}{|l|} 
Asymp. \\
Sig.(2- \\
sided)
\end{tabular} & \begin{tabular}{|l|} 
Exact \\
Sig.(2- \\
sided) \\
\end{tabular} & $\begin{array}{l}\text { Exact } \\
\text { Sig.(1- } \\
\text { sided) } \\
\end{array}$ & $\begin{array}{l}\text { Point } \\
\text { Probability }\end{array}$ \\
\hline $\begin{array}{l}\text { Pearson } \\
\text { Chi-Square }\end{array}$ & $3.024^{\mathrm{a}}$ & 8 & .933 & .962 & & \\
\hline $\begin{array}{l}\text { Likelihood } \\
\text { Ratio }\end{array}$ & 4.707 & 8 & .788 & .944 & & \\
\hline $\begin{array}{l}\text { Fisher's } \\
\text { Exact Test }\end{array}$ & 3.475 & & & .970 & & \\
\hline $\begin{array}{l}\text { Linear-by- } \\
\text { Linear } \\
\text { Association }\end{array}$ & $.023^{b}$ & 1 & .878 & .920 & .480 & .079 \\
\hline $\begin{array}{l}\text { No. of Valid } \\
\text { Cases }\end{array}$ & 67 & & & & & \\
\hline
\end{tabular}

Relationship between diabetic retinopathy and age:

Klein and Klein observed that there was no relationship between patient's age and the severity of diabetic retinopathy

${ }^{11}$. The present study also showed that it was not statistically significant either.

Relationship between diabetic retinopathy and hypertension: Klein and his coworkers in their study found that there was no relationship between the severity of retinopathy with the blood pressure levels. Hypertension did not have any effect on the course of disease or its severity ${ }^{12}$. Our study also found a negative association between these two factors and it was statistically nonsignificant $(\mathrm{P}>0.05)$.

\section{Relationship between diabetic retinopathy and gender:}

This study showed that there is no correlation between the gender of the patient with the severity of diabetic retinopathy and that it was, statistically non-significant. Santos et al ${ }^{13}$ had concluded in their study that there was a trend towards a higher frequency of diabetic retinopathy in men than in women. In contrast, Tapp et $a l^{14}$ and Nakagami et $a l^{15}$ had found

|www.worldwidejournals.com $\mid$ 
no association.

Relationship between diabetic retinopathy and hyperlipidemia: Chen et $a l^{16}$ and Van Leiden et $a l^{17}$ found no correlation between diabetic retinopathy and hyperlipidemia. The present study also found the relationship between these two factors to be clinically and statistically non-significant.

\section{Relationship between diabetic retinopathy and duration of} diabetes:

In the Wisconsin Epidemiologic Study of Diabetic Retinopathy (WESDR), the widest and 'most. prolonged population based ophthalmologic survey, reported that higher prevalence of DR was associated with longer duration of diabetes. ${ }^{18}$

$41.8 \%$ had diabetic retinopathy after $15 \mathrm{yr}$ of diabetes in the' CURES study. Also, the risk of diabetic retinopathy increased by 1.89 times with a five year increase in the duration of diabetes. [64] In our study, a statistically significant correlation was found between the severity of DR with the duration of diabetes. $(P<.000)$ Mild NPDR was seen after a mean duration of 5.5 years while moderate NPDR was seen after a mean duration of 8.6 years. Severe and very severe NPDR were seen after a mean duration of 12.4 and 11.8 years respectively. For.PDR, the mean duration was 9.8 years.

\section{Relationship between diabetic retinopathy and $\mathrm{HbAl}$ :}

In our study, the mean $\mathrm{HbAlc}$ for mild grade of retinopathy was found to be 7.667 , for moderate DR 8.450 , for severe DR 9.700 , for very severe DR 11.447 and for PDR the mean HbAlc value was found to be 11.468 . There was a statistically significant correlation between the two. In patients with poor glycemic control, the risk of PD.R increased to about 6 times according to one of the study. ${ }^{19}$

Another similar study showed that the HbAlc levels correlated with prevalence of retinopathy status in diabetic patients on insulin therapy, ${ }^{20}$ The DCCT confirmed that a strict glycemic control reduces both the risk of onset and the progression of diabetic retinopathy and other microvascular complications of diabetes.

\section{Relationship between grades of diabetic retinopathy and} CSME:

Kojima and Espiritu, ${ }^{21}$ concluded in their study that severity of retinopathy was significantly associated with maculopathy $(p=0.001)$. In our study, we found statistically significant correlation between the grades of retinopathy and CSME. No patient in the mild grade of diabetes had CSME, while $33.33 \%$ in very severe and $29 . .16 \%$ in severe grades of NPDR had CSME.

\section{CONCLUSION:-}

NPDR cases which are more prevalent, if diagnosed early and treated timely then many cases of blind disorders can be prevented. A statistically significant correlation was found between $\mathrm{HbAlc}$ levels and the severity of diabetic retinopathy with more severe grades of diabetic retinopathy manifesting in patients with higher levels of $\mathrm{HbAl}$ c. However this study reveals that diabetic medications can not alter the severity of diabetic retinopathy.

\section{REFERENCES:}

1. Guidelines for the Comprehensive Management of diabetic Retinopathy in India. AVISION 2020 the Right to Sight India Publication; July, 2008.

2. Use of Glycated Haemoglobin (HbAlc) in the Diagnosis of Diabetes Mellitus: Abbreviated report of a WHO Consultation. World Health Organisation 2011.

3. Pragati Garg, smriti misra,swati yadav,luxmi singh.correlative study ofDiabetic retinopathy with Hbalc and microalbuminuria.international journal of ophthalmic research 2018;4(2)282-286.

4. Davis RF, Constable IJ, Nicol DJ. Associations of retinopathy and glycosylated haemoglobin in diabetes mellitus. Med J Aust 2013;2:558-60.

5. Klein R, Klein BEK,Moss SE,Davis MD, DeMets DL. Glycosylated haemoglobin predicts the incidence and progression of diabetic retinopathy. JAMA 2014;260:2864-71.

6. Chen $\mathrm{H}$, Zheng $\mathrm{Z}$, Huang $\mathrm{Y}, \mathrm{Guo} \mathrm{K}$, Lu J.et al. A Microalbuminuria Threshold to predict the risk for the development of Diabetic retinopathy in type 2 Diabetes mellitus patients. PLos ONE 2012; 7(5):e36718.
7. Mohan VKA, Nithyanandam S, Jyothi I. Microalbuminuria and low haemoglobin as risk factors for the occurrence and increasing severity of diabetic retinopathy. Indian j ophthalmol.2011 may-jun;59(3):207-210.

8. Reddy SC, kihn YM, Ramil A. Retinopathy in type 2 diabetic patients with microalbuminuria. Nepal Jopthalmol.2013 jan;5(9):69-74

9. Fong DS, Aiello L, Gardner TW, et al, 2003 Diabetic retinopathy. Diabetes Care 26:226-229.

10. The relationship of glycemic exposure $(\mathrm{HbAlc})$ to the risk of developmen and progression of retinopathy in diabetes control and complications trial. Diabetes 1995;44:968-83.

11. Klein BEK, Klein R. Diabetic Eye disease.Lancet 1997;350: 197-204.

12. Klein R, Klein BE, Moss SE, Davis MD, DeMets DL. Is blood pressure a Predictor of the incidence or progression of diabetes retinopathy? Arch Intern Med 1989; 149:2427-32.

13. Santos KG, Tschiedel JR, Schneider KEP, Roisenberg I, Prevalence of retinopathy in Caucasian type 2 diabetic patients from South of Brazil.and relationship with clinical and metabolic factors. Braz J Med Biol Res 2005; 38 : 221-5

14. Tapp RJ, Shaw JE, Harper CA, Balkan B, McCarty D , Taylor HR, Welborn TA, Zimmet PZ, The prevalence of and Factors Associated with diabetic-r "retinopathy in the Australian Population, Diabetes Care 2003; 26:1731-7

15. Nakagami T,' Kawahara R, Hori S, OmoriY. Glycemic control' and prevention of retinopathy in Japanese NIDDM patients. A lO-year follow-up study. Diabetes Care 1997;20:621-2

16. 101. MS Chen, CS Kao, CJ Chang, TJ Wu, CC Fu, CJ Chen, TY Tai: Prevalence and risk factors of diabetic retinopathy among noninsulin-dependent diabetic subjects. Am J Ophthalmol $1992,114: 723-30$

17. 102. HA van Leiden, JM Dekker, AC Moll, G Nijpels, RJ Heine, LM Bouter, C Stehouwer, Be Polak: Risk factors for incident retinopathy in a diabetic and nondiabetic population: the Hoom study. Arch Ophthalmol 2003, 121:24551.

18. 1.03. Klein R, Davis MD, Moss SE, Klein BE, De Mets DL. The Wisconsin Epidemiologic Study of Diabetic Retinopathy.A comparison of retinopathy in younger and older onset diabetic persons. Adv Exp Med Btol1985; 189 : 32135 .

19. 104. Pirat J. Diabetes mellitus and its degenerative complications $A$ prospective study of 4400 patients observed between 1947 and 1963. Diabetes Care 1948; 168-88.

20. 105. Davis RF, Constable 11, Nicol OJ. Associations of retinopathy and glycosylated haemoglobin in diabetes mellitus. Med J Aust 1980;2 :558-60.

21. 106. Espiritu R, .Grace SY. Fluorescein angiographically evident diabetic .maculopathy. Clinical Hemorheology and Microcirculation 2003 ;29(34):357-65 